\title{
EVOLUTION OF PROFESSIONAL COMPETENCIES OF ACCOUNTANTS OF SMALL ENTERPRISES IN THE DIGITAL ECONOMY OF UKRAINE
}

\begin{abstract}
Alla Zhyvets ${ }^{1}$
Abstract. At present, the accountant's workplace is the most "digitized" at enterprises. It is equipped, on average, with five units of computer, office and communication equipment, and also, on average, seven software products for automation of accounting work are applied. However, university graduates state that their knowledge and skills correspond only to $45 \%$ of the requirements of the modern automated workplace of the accountant. Higher education institutions have lagged far behind in the applied "digital" competence of accountants. The purpose of the article is to identify key directions for improving the professional "digital" training of accountants. Research methods. The author carried out a questionnaire survey of 120 small and micro enterprises with coverage of the majority of operating sectors of the economy; carried out a questionnaire survey of IT companies managers dealing with automation of managerial work at the enterprises; training plans for accountants auditors for availability and quality of digital technologies training were studied, foreign experience in training of accountants following the publications of research organizations: Hitachi Data Systems, Global Education Future, Fujitsu, McKinsey Global Institute, PwC was studied. Results. The researches of the evolution of the professional competencies of accountants carried out by the author show a lag in the content of their "digital" training from the real proficiency requirements for work at an automated workplace of the accountant of an enterprise. Conclusions and offers. Education of accountants and their further continuous professional training should focus on the development of digital technologies of the implementation of the entire economic block of enterprise managerial works on the basis of existing software and cloud services. The author developed proposals for improving the professional training of accountants of small enterprises.
\end{abstract}

Key words: evolution of qualification of accountant of small enterprise, development trends of accountant's competencies, cognitive competencies, digital economy technologies in management.

JEL Classification: A22, M41

\section{Introduction}

The main trend in the development of industry and national economies in the early 21 st century is the introduction of digital technologies. These same technologies make it possible to increase labour productivity, significantly reduce the time for designing and developing new products, reduce the technological and financial cycles of products manufacture and realization, as well to enter global markets.

At the present time, the economic bloc of work at enterprises is $2 / 3$ based on the use of digital technologies. But with the current rapid development of IT technologies at enterprises, the following problem arose: the digital competence of the staff is significantly behind the increased capabilities of IT technologies in enterprise management. There are several reasons but the main one lies in the fact that educational institutions "lag behind" in teaching "digital" technologies. And this

Corresponding author:

${ }^{1}$ Odessa National Polytechnic University, Ukraine.

E-mail: zhivets.alla@ukr.net lag is typical not only for the taught vocational subjects but also for the applied teaching methods.

The author's research showed that $55 \%$ of accounting graduates are not ready to work for the AWS of a chief accountant of the small and micro enterprises (SE and $\mathrm{ME}) ; 38 \%$ of the accounting graduates at the beginning of the working career were additionally trained in the courses "1C: Accounting for Ukraine"; $69 \%$ of the accounting graduates noted the inadequacy of applied digital training for specific work at the enterprise (Zhyvets, 2017).

The importance of the "digital" training of accountants is indicated by the recommendations of the International Federation of Accountants (IFAC). So, in the standard (IES) 2 "Content of the Professional Accounting Education Program" in the third block of education disciplines "Information technology and authority" the following subjects (knowledge areas, competencies) are indicated: 
- general knowledge of information technology;

- knowledge of control capabilities of information technology;

- the range of information technology opportunities;

- the ability to use information technology in work;

- the presence of one or more qualifications: a manager, an expert or an information systems developer.

It is noted that modern enterprises using "Big Data" technologies significantly increase the work quality level of accountants in terms of implementation of deeper economic analytics and high speed of providing managerial information.

The author pays a particular attention to the introduction of digital technologies in the SE and ME, as they currently constitute $95 \%$ of the total number of enterprises in the Ukrainian economy (State Statistics Service of Ukraine, 2017).

Analysis of recent researches and publications. The problem of improving the training of accountants in universities is devoted to many works of both Ukrainian and foreign scientists. Particularly in detail this problem is studied by such scientists as T. P. Alaverdova (2012), V. G. Hetman (2010), S. Ya. Zubilevich (2015), O. V. Kuklin (2011), V.A. Lukin (2013) and many others.

Basically, in domestic and foreign scientific publications, the approach to the problem of improving the training of accountants is considered from the standpoint of the development of accounting science, which, according to the author, is only partially true, as the functions of the modern accountant have significantly expanded and evolved, especially in the SE and ME.

The content of the work of the accountant of the SE and ME is constantly changing, some of his functions are integrated into various subsystems of enterprise management, as a result of which the accountant becomes a "co-manager" of the enterprise and his role in this process is constantly increasing. This is noted by all the researchers mentioned above.

The author states that the management functions assigned to accountants can be redistributed between the officials of the management team of the enterprise and, as a result, the professions altered in content may appear. This applies especially to microenterprises numbering up to 10 people, where the division of managerial work is fundamentally different from the division of managerial work in large enterprises.

Therefore, in our "Ukrainian economy", where the SE and ME constitute 95\%, and microenterprises $-85 \%$, there is a situation with the division of labour of engineering staff workers that the integration of managerial functions is dominant in job creation, as well as in the formation of job descriptions and requirements to a set of competencies for hired workers. At present, multifunctionality is a worldwide trend in the evolution of managerial work within the conditions of the digital economy.
The purpose of the article is to identify key directions for improving the professional "digital" training of accountants in higher education institutions on the basis of studying the world's experience of introducing digital technologies into management practices.

\section{Results of the study of accountants competence}

To solve the set task, the author carried out the following research activities:

1) a questionnaire survey of accountants of 120 small and micro enterprises in the regions of southern Ukraine was carried out covering the majority of the operating sectors of the economy;

2) a questionnaire survey of the heads of IT companies involved in the automation of managerial works at enterprises in the regions of southern Ukraine was carried out;

3) training plans for accountants auditors in universities of the regions of southern Ukraine for the availability and quality of teaching digital technologies were studied;

4) foreign experience in training of accountants following the publications was studied:

- international research organizations: Hitachi Data Systems (2016), Global Education Future (2016), Fujitsu (2017), McKinsey Global Institute (2017), $\mathrm{PwC}$ (2016);

- domestic research organizations: the National Institute for Strategic Studies, State Statistics Service of Ukraine.

The first results of the questionnaire survey of the accountants of SE and ME show the following situation in the professional training of accountants (Zhyvets, 2017):

1 ) in the majority of small and micro enterprises ( $88 \%$ of the enterprises surveyed), the accountant performs, in addition to exclusively accounting functions, also the functions of an economist, financier, business lawyer, human resources manager, an expert in company automated control system, etc.;

2) a graduate with a degree in Accounting and Audit comes to the enterprise with a store of theoretical knowledge only in accounting and auditing. Therefore, graduates, now practicing accountants of small and micro enterprises, estimate the degree of their readiness to perform the work of the accountant of a small enterprise, in view of today's requirements, only by $45 \%$ (according to the questionnaire of accountants of SE and ME in 2016-2017);

3) all interviewed accountants of the SE and ME note that their workplaces are equipped with PCs and other electronic office equipment and that their work is based on digital technologies; $59 \%$ of accountants note the critical importance of digital competence for working in a modern workplace of the accountant. 


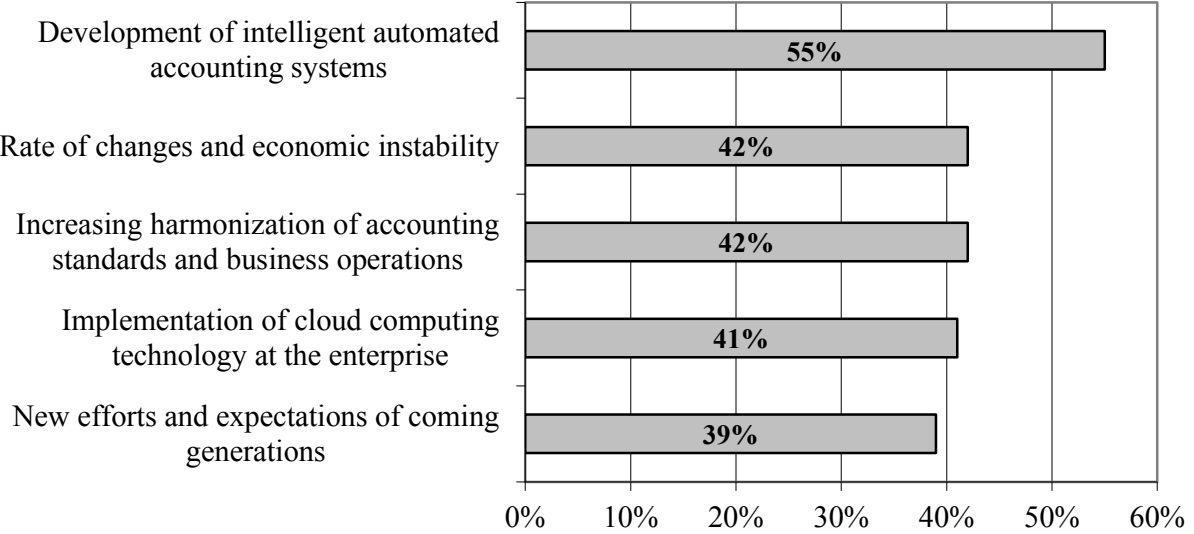

Figure 1. External factors that have the most significant impact on the content of the work of an accountant

Source: the author's survey on the basis of (ACCA, 2016)

According to foreign researchers, the change in the work of the accountant and auditor is fundamentally influenced by the introduction of digital technologies. ACCA research identifies the factors most influencing the methods of work of accountants (Figure 1). The main conclusions made by the ACCA experts are as follows:

- the greatest impact on the reengineering of accounting at enterprises in the next 10 years will be made by the development of intelligent automated accounting systems;

- in a modern enterprise, the accountant is, first and foremost, a strategist, a professional capable of generating and implementing business development ideas and activities.

\section{Assessment of the "digital" competence of accountants}

It appears that the most objective assessment of the "digital" competence of accountants is the evaluation given by IT specialists of companies implementing IT-products at enterprises. Such IT-specialist not only installs the necessary software for automation of accounting and other office works but also provides training for customer-users to efficient use of the acquired software product. Therefore, joint work with accountants allows you to objectively assess their willingness to work with digital technologies.

The survey of leading specialists of IT companies implementing IT-technologies made it possible to determine the evaluation of the "digital" competence of accountants of the SE and ME (Table 1).

In the same survey, experts gave a verbal assessment of the "digital" competence of accountants:

1) young accountants (a group of up to 22 years old) easily perceive the automation of accounting work but do not have sufficient practical experience in organizing accounting and analysis at the enterprise and a clear understanding of the business mechanism of the enterprise, so the process of implementing intelligent automated accounting systems is associated with additional training of the accountant;

2 ) accountants in the age group of $22-40$ years are the most prepared for the development of new accounting programs. They have experience with various simple office programs;

3 ) in the older age group of accountants there is conservatism and some "non-perception" of IT technologies, which, according to experts, is a consequence of the insufficiency of IT education (20-30 years ago); 4) accountants of the age group of 22-40 years absorb and apply analytical applications to the accounting automation programs at enterprises easier than other; 5) basically "digital" training of accounting graduates is assessed by experts as "below average".

Interesting material for describing the digital content of the work of accountants of the SE and ME gives their answers to the question: "What programs for the PC do you use in your work?" Here the answers of the respondents (working accountants) were distributed as follows (Table 2).

Table 1

Evaluation of the "digital" competence of accountants of the SE and ME

\begin{tabular}{|l|c|c|c|c|c|c|}
\hline \multirow{2}{*}{ Index name } & \multicolumn{5}{|c|}{ Overall assessment of the digital competence of accountants by age group } \\
\cline { 2 - 7 } & $20-22$ years & $22-30$ years & $30-35$ years & $35-40$ years & $40-50$ years & 50 years \\
\hline $\begin{array}{l}\text { "Digital" competence of accountants } \\
\text { (on a scale from one to ten) }\end{array}$ & 5 & 7 & 8 & 6 & 5 & 3 \\
\hline
\end{tabular}

Sources: compiled by the author 
Table 2

List of software tools used in the work of the accountant of SE and ME

\begin{tabular}{|c|l|c|}
\hline $\begin{array}{c}\text { Ser. } \\
\text { No. }\end{array}$ & $\begin{array}{c}\text { Name of programs, software } \\
\text { packages, information systems } \\
\text { used in the work of accountants }\end{array}$ & $\begin{array}{c}\text { Number of } \\
\text { respondents applying } \\
\text { these programs, \% }\end{array}$ \\
\hline 1 & 1C: Accounting for Ukraine & 95 \\
\hline 2 & M.E.Doc & 81 \\
\hline 3 & Sonata & 2 \\
\hline 4 & Payer Account & 5 \\
\hline 5 & MS Word & 100 \\
\hline 6 & Online Banking & 14 \\
\hline 7 & Email & 100 \\
\hline 8 & Sail & 2 \\
\hline 9 & Excel & 100 \\
\hline 10 & BI-systems & 5 \\
\hline
\end{tabular}

Source: compiled by the author

The results of the questionnaire make it possible to conclude that a graduate of the university with a degree in "Accounting and Audit" must have, a priori, professional skills to work with the following accounting and office work applications (1C: Accounting for Ukraine, MS Word, M.E.Doc, Excel), as well as skills in working with modern office equipment. Such modern management tools as BI-systems, which effectively advance the promptness and quality of business operations, are not yet implemented in accounting departments in sufficient quantities. Currently, these services and programs are still expensive for most $\mathrm{ME}$ and a part of the SE. A small list of programs used by respondents required additional study of the software market for the activities of the SE and ME in Ukraine.

The author's research showed that in the market of software and information technologies in Ukraine, the following groups of systems, programs and services are available (there are from 10 to 20 programs and services in each group):

- accounting software and services for delivery of reports via the Internet;

- business management systems and programs for business intelligence;

- systems BPM, ERP, CRM;

- corporate program management systems;

- online HRM systems for human resource management;

- software for recruiting;

- Internet portals for collaboration and access to information;

- postal services;

- EDM systems for workflow automation;

- ECM systems for managing of corporate content;

- electronic workflow operators for the exchange of electronic documents;

- services for online seminars, conferences, online meetings;

- virtual PBX - cloud services for communications and managing of incoming calls;
- instant messengers for instant messaging;

- WIKI services and engines for organizing workspace for team-work and for file storage.

These data show that there are a sufficiently large number of programs in the IT-market of Ukraine for solving a wide range of tasks for the management of $\mathrm{SE}$ and ME. All this complex of programs and services allows currently to support such modern trends in the development of management of SE and ME as: virtual enterprises, remote working, e-business, "lean production", "virtual staff", effective use of global information systems etc.

It also should be noted that currently in SE and ME environment distance employment is gaining wide development in Ukraine: according to the research of the companies Bitrix 24 and GfK Ukraine, $21 \%$ of the SE and the ME use distance employment to optimize their loading (2016). Among them, $17 \%$ of accountants work in remote workplaces (usually at home). In the future, in 2020, $36 \%$ of accountants will work with partial and distance employment. All necessary software for the remote working of accountants in Ukraine is already available.

\section{Determination of trends in the development of accountants' competencies}

In the further study of the current day competencies of accountants, we suggested respondents cover the issue of their professional competence from different points of view. So, to the question, "What current basic professional knowledge and competencies should a graduate - the future accountant of SE - have?" the following answers were received (Table 3 ).

The data of Table 3 show that $67 \%$ of the currently required knowledge and skills of modern accountants are connected with digital competence.

That is, a modern accountant can't exist at all without "digital» competence. Now the accountant is the most "digitized" specialist at the enterprise.

Further analysis of respondents' answers showed that nowadays the accountant of the SE and the ME performs by himself from $69 \%$ to $88 \%$ of all the works included in the "economic block" of enterprise management.

The author draws a special attention to the fact that the list of areas of activity, as well as the required skills of the accountant of the SE and ME (Table 3), is also a list of areas for improving the training of future accountants in the current conditions of the evolution of the national economy.

The above results of the research of the "digital" competency of accountants objectively characterize the current state of their preparation. But for adjustment of the university training programs for the specialists of the 21st century, it is necessary to see and to understand the evolution and trends in the development of the competences of the engineering staff worker in the digital economy and the knowledge economy. 
Table 3

The list of knowledge and competencies of accountants demanded at the enterprises

\begin{tabular}{|c|l|c|}
\hline $\begin{array}{c}\text { Ser. } \\
\text { No. }\end{array}$ & \multicolumn{1}{|c|}{ Name of demanded knowledge and competences } & $\begin{array}{c}\text { The number of respondents who noted } \\
\text { the importance of this position, } \%\end{array}$ \\
\hline 1 & National accounting standards (regulations) & 57 \\
\hline 2 & International accounting standards & 67 \\
\hline 3 & The content, structure and main regulations of the Tax Code of Ukraine & 59 \\
\hline 4 & Practical skills of work with accounting programs: 1C: Enterprise, 1C: Accounting for Ukraine & 59 \\
\hline 5 & Ability to work with programs: M.E.Doc, Excel & 43 \\
\hline 6 & $\begin{array}{l}\text { Ability to work with reference and information systems: League: Law, Lawyer +, sites of GFS } \\
\text { of Ukraine, the Ministry of Finance of Ukraine etc. }\end{array}$ \\
\hline 7 & Knowledge of the basics of economic law, an organization of contractual and claim work & 60 \\
\hline 8 & Knowledge of labour law, Labour Code of Ukraine, staff records management & 52 \\
\hline 9 & Organization of workflow at the enterprise & 33 \\
\hline 10 & Fundamentals of enterprise budgeting & 5 \\
\hline 11 & Organization of management accounting & 29 \\
\hline 12 & Fast typing skills & \\
\hline 13 & Skills of work with all office equipment & 14 \\
\hline 14 & Skills of documents' capture for creating enterprise data banks & 14 \\
\hline 15 & Knowledge of foreign languages & 10 \\
\hline
\end{tabular}

Source: compiled by the author

Such an international study was carried out by the IT company "Fujitsu" in 2017. Having researched the trends and peculiarities of the development of the digital economy in a number of industrialized countries (1600 business leaders were interviewed), the experts of Fujitsu not only identified the problems of the development of digital technologies but also presented their vision of the development of employees' competencies in the 21 st century (Table 4 ).

The data of Table 4 show that with the growth of the level of industrial development of countries, as well as with the growth of the level of development of information and communication technologies, the "image" of a competent young specialist is evolving.

For example, in Spain (the level of development-Industry3.0), this “image" is characterized by the following set of four main competencies:

- on the first place - high professional knowledge of business organization (i.e. emphasis on organization and finance);
- on the second - use of digital technologies;

- on the third - use of creative abilities and development of imagination;

- on the fourth - ability to logical thinking and analysis.

In Germany (the level of development - Industry 4.0), this "image" is characterized by the same set of four main competences, but with a different priority:

- on the first place - use of creative abilities and development of imagination;

- on the second - use of digital technologies;

- on the third - the ability to logical thinking and analysis; - on the fourth - professional knowledge of the specifics of the business organization.

In Japan (the level of development - Industry 5.0, Society 5.0), this "image" is characterized by a different set of four main competencies and with their other priorities: - on the first place - use of high creative abilities and development of imagination (human activity becomes more intellectual);

Table 4

The most important competencies of employees in the digital age

\begin{tabular}{|c|l|c|c|c|}
\hline \multirow{2}{*}{$\begin{array}{c}\text { Ser. } \\
\text { No. }\end{array}$} & \multicolumn{1}{|c|}{ Name of competences, knowledge } & \multicolumn{3}{|c|}{ Specific value of competences, knowledge } \\
\cline { 2 - 4 } & & Spain & Germany & Japan \\
\hline 1 & Professional knowledge of digital technologies & $\mathbf{1 8 , 4}$ & $\mathbf{1 4 , 6}$ & 10,0 \\
\hline 2 & Creative abilities and development of imagination & $\mathbf{1 5 , 5}$ & $\mathbf{1 5 , 5}$ & $\mathbf{2 6 , 5}$ \\
\hline 3 & Professional knowledge in a particular industry & 7,8 & 9,7 & $\mathbf{1 0 , 4}$ \\
\hline 4 & Professional knowledge of the specifics of the business organization & $\mathbf{1 8 , 4}$ & $\mathbf{1 1 , 7}$ & 8,1 \\
\hline 5 & Ability to logical thinking and analysis & $\mathbf{1 1 , 7}$ & $\mathbf{1 2 , 6}$ & 7,8 \\
\hline 6 & Knowledge in the field of special and human sciences & 7,8 & 8,7 & 3,6 \\
\hline 7 & Ability to decision-making & 8,7 & 8,7 & $\mathbf{1 1 , 7}$ \\
\hline 8 & Leadership qualities & 6,8 & 9,7 & 6,5 \\
\hline 9 & Sociability and empathy & 2,9 & 5,8 & $\mathbf{1 1 , 0}$ \\
\hline 10 & Professional excellence & 1,0 & 1,0 & 2,3 \\
\hline
\end{tabular}

Source: the author's review on the basis of (Fujitsu, 2017) 
- on the second - ability to make independent decisions; - on the third - use of communication and empathy (in the conditions of collective creative activity); - on the fourth - use of professional knowledge in a specific field of production (this is an important trend for the development of education).

We note that "digital" competence in highly developed countries is already perceived as a necessary basic level of education of a young specialist, as well as a certificate of employers' confidence in the level of "digital" training in universities.

Generalization of the results of research of the company "Fujitsu" on the evolution of the employees' competencies in the group of developed countries shows that in the future digital society (the next 5 years) the following competencies will be particularly in demand:

- creative abilities and development of imagination;

- professional knowledge of digital technologies;

- ability to logical thinking and analysis;

- professional knowledge of the specifics of the business organization.

When preparing accountants for small and microenterprises in our Ukrainian reality, it is necessary to take into account all the 10 competencies listed in Table 4.

\section{Conclusions}

Our studies of the evolution of professional competencies of accountants in the conditions of the development of the digital economy of Ukraine made it possible to draw the following conclusions:

1. The general trend of the development of the professional competences of accountants of the SE and $\mathrm{ME}$ is the learning of digital technologies for the implementation of the entire economic block of the company's operations on the basis of existing software and cloud services.

2. The range of functional duties and tasks solved by the accountants of the SE and $\mathrm{ME}$ at their workplaces requires adjustment of the plans of study for their training in educational institutions. In the plans of study, the following blocks of disciplines should be strengthened:

- management accounting; rationing, planning, accounting, and analysis of the use of material and energy resources;

- organization of labour and wages, methods of stimulation of the labour of the staff;

- staff records management, the Labour Code;

- management of the enterprise economy;

- business planning, organization and analysis of economic activities;

- management of finances and other assets of the enterprise;

- economic law, an organization of contractual and claim work.

3. It is necessary to introduce in the practice of the teaching of all special disciplines practical training with the use of progressive software of AWS of the accountant. Tasks and examples for all disciplines should be taken from the real economic practice of enterprises and deliberately oriented towards the application of specific software.

A graduate should be $100 \%$ prepared for work at the AWS of the company's accountant.

4. To introduce in the universities the practice of attracting specialized training firms to automate accounting for internships and attestation of graduate accountants for mastering basic accounting and analytical programs (1C: Accounting for Ukraine, Sail etc.).

\section{References:}

Alaverdova, T. P. (2012). On the issue of basic professional education of accountants for small business. Retrieved March, 2017 from: http://www.sworld.com.ua/index.php/uk/economy-412/accounting-andauditing-412/15774-412-0218 (in Russian)

Fujitsu (2017). Fujitsu Technology and Service Vision. Retrieved March, 2017 from: http://www.fujitsu.com/ global/microsite/vision/insightful-stories/surveyl/

Getman, V. G. (2010). Modern approaches to university training of accountants and auditors. Journal of Accounting in publishing and printing, 11(251), 2-11. (in Russian)

Hitachi Data Systems (2016). In the next two years the business is waiting for rapid digital changes. Retrieved March, 2017 from: http://www.hitachivantara.com/ru-ru/news-resources/press-releases/2016/ru161129.html

Kuklin, O. V. (2011). Modernization of Higher Education in Ukraine: Strategic Principles, Trends and Directions of Implementation. Journal of Scientific reporter of CSIEM, 4(12), 34-39. (in Ukrainian)

Lukin, V.A. (2013). Formation of accounting training programs in Ukrainian universities. Journal of Business inform, 1, 252-257. (in Ukrainian)

GfK \& Bitrix 24 (2016). Remote work in Ukraine: statistics and forecasts from GfK and Bitrix 24. Retrieved March, 2017 from: http://www.hi-tech.ua/distantsionnaya-rabota-v-ukraine-statistika-i-prognozyi-ot-gfk-ibitrix-24/

Global Education Future (2016). Skills of the future and transformation of the global educational ecosystem. Retrieved March, 2017 from: http://www.edu2035.org/

State Statistics Service of Ukraine (2017). Kyiv: Informatsiino-analitychne ahentstvo. Retrieved March, 2017 from http://www.ukrstat.gov.ua/ 
ACCA (2016). Tomorrow's world: rethinking the role of the accountant. Retrieved March, 2017 from: http://future.accaglobal.com/the-future-of-accountancy/insight-articles/tomorrows-world-rethinking-the-roleof-the-accountant

McKinsey Global Institute (2017). What is the future of work? Retrieved March, 2017 from: http://www.mckinsey.com/ global-themes/future-of-organizations-and-work/what-is-the-future-of-work

PwC (2016). Workforce of the future: The competing forces shaping 2030. Retrieved March, 2017 from: http://www.pwc.com/gx/en/services/people-organisation/publications/workforce-of-the-future.html

Zhyvets, A. N. (2017). Trends of professional competences development for small companies' accountant in the 21st century. Journal of Actual problems of economics, 6, 204-213. (in Ukrainian)

Zubilevych, S. Ya. (2015). International standards for training professional accountants: "reboot". Retrieved March, 2017 from: http://uabs.edu.ua/images/stories/docs/9956/zubilevich.pdf (in Ukrainian) 